$\frac{141}{7-29-80}$ LA-8457-MS

Informal Report

Dr. 1792

\author{
An Overview of the \\ National Uranium Resource Evaluation \\ Hydrogeochemical and Stream Sediment \\ Reconnaissance Program
}

은

¿

क

事

$\frac{2}{5}$ 
LA-8457-MS

Informal Report

UC-51

Issued: July 1980

\title{
An Overview of the \\ National Uranium Resource Evaluation \\ Hydrogeochemical and Stream Sediment \\ Reconnaissance Program
}

\author{
Stephen L. Bolivar
}

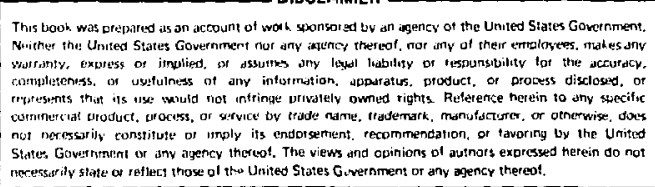

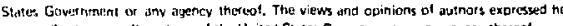

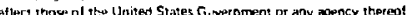

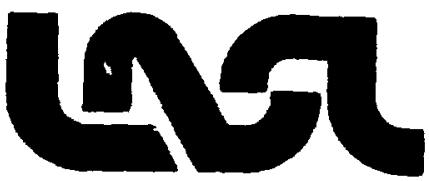




\section{CONTENTS}

LIST OF FIGURES vi

LIST OF TABLES vi vi vis

ABSTRACT

I. INTRODUCTION 2

II. RECONNAISSANCE (EOCHEMICAL EXPLORATION 3

III. THE SEARCH FOR JRANIUM

Sample Media Used in the HSSR Program 4

Ancillary Elements 7

IV. SETTING UP AN HSSR PROGRAM $\quad 7$

V. FIELD MEASUREMENTS 10

VI. SAMPLE COLLECTION

LASL 12

ORGDP 13

$\begin{array}{lr}\text { SRL } & 13\end{array}$

VII. FIELD OBSERVATIONS

VIII. SAMPLING DENSITIES

LASL

ORGDP

SRL

$\begin{array}{ll}\text { DATA AVAILABILITY } & 20\end{array}$

ACKNONLEDGMENTS

REFERENCES CITEL 


\section{LIST OF FIGURES}

Fig. No.

1. Index map showing regions of responsibility, pilot study areas, and NTMS quadrangle boundaries for the HSSR program. 2

2. Typical field instruments used in the HSSR program. 11

3. Typical filter assemblies used in the HSSR program. 13

4. Bottom sampler used to obtain lake sediments in Alaska. 14

5. Representative data form used in the HSSR program. 16

6. Major physiogrphic provinces for the HSSR. 19

\section{LIST OF TABLES}

Table No.

I. Typical Sample Media Used in Reconnaissance Geochemical Sampling

I.I. Field Measurements, Nominal Sampling Densities, and Chemical Analyses for the HSSR Program

III. Steps in Setting Jp an HSSR Program 8

IV. Technical Parameters to Consider in Designing and Undertaking an HSSR Program

V. Some Parameters to be Considered in Field Measurements 10 
AN OVERVIEW OF THE

NATIONAL URANIUM RESOURCE EVALUATION

HYDROGEOCHEMICAL AND STREAM SEDIMENT RECONNAISSANCE PROGRAM

\author{
by \\ Stephen L. Bolivar \\ ABSTRACT
}

A Hydrogeochemical and Stream Sediment Reconnaissance (HSSR) for uranium is currently being conducted throughout the conterminous United States and Alaska. The HSSR is part of the National Uranium Resource Evaluation sponsored by the US Department of Energy.

This ambitious geochemical peconnaissance program is conducted by four Department of Energy laboratories: Los Alamos Scientific Laboratory, Lawrence ILivermore Laboratory, Dak Ridge Gaseous Diffusion Plant, and Savannah River Laboratory. Each laboratory was assigned a geographic region of the United States. The program is based on an extensive review of world literature, reconnaissance work done in other countries, and pilot studies conducted by each laboratory. Sample-collection methods and sample derisity are determined to optimize the probability of detecting potential uranium mineralization. To achieve this aim, each laboratory has developed independent standardized field collection procedures that are designed for its section of the country. Field parameters such as $\mathrm{pH}$, conductivity, climate, geography, and geology are recorded at each site. Most areas are sampled at densities of one sample site per 10 to $23 \mathrm{~km}^{2}$.

The HSSR program has helped to improve existing hydrogeochemical reconnaissance exploration techniques. In addition to providing industry with data that may help to identify potential uranium districts and to extend known uranium provinces, the HSSR also provides multielement analytical data that can be used in water quality, soil, sediment, environmental, and base-metal exploration studies. 
In 1973, the Atomic Energy Commission initiated a National IJanium Resource Evaluation (NURE). The major objective of this program is the assassment of the nuclear fuel resources in the conterminolds US and Alaska (US Department of Energy, 1979). The NURE program is now administered by the Department of Energy (DOE) and consists of hydrogeochemical and siream-sediment reconnaissance, airborne radiome'jic surveys, topical geologic studies, "worldclass" ore deposit studies, subsurface geologic investigations, technology applications, and resource estimation methodology.

This report addresses the Hydrogeochemical and Stream Sediment Reconnais... sance (HSSR). Four DOE laboratories, Lawrence Livermore Laboratory (LLL), LOS Alamos Scientific Laboratory (LASL), Oak Ridge Gaseous Diffusion Plant (ORGDP), and Savannah River Laboratory (SRL), have conducted the hydrogeochemical program. Regions of responsibility are shown in Fig. 1. Each laboratory developed its own geochemical reconnaissance program for uranium based on time and funding constraints and emphasized the determination of uraniam concentrations in both natural waters and waterborne sediments. This report summarizes the programs developed by the LASL, ORGDP, and SRL. The LLL program is not discussed because of the very small areal coverage by this laboratory.

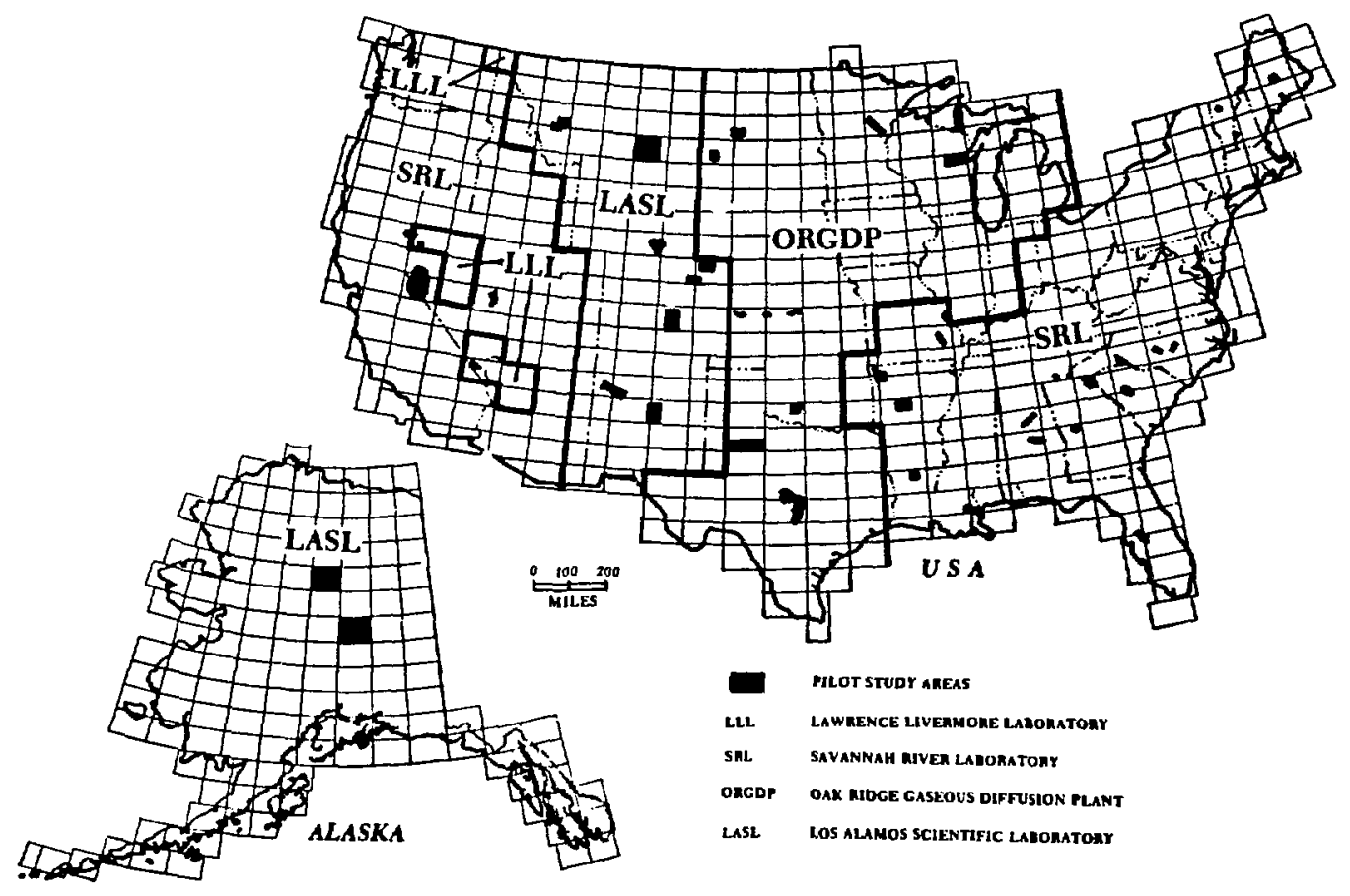

Fig. 1. Index map showing regions of responsibility, pilot study areas, and NTMS quadrangle boundaries for the HSSR program. 


\section{RECONNAISSANCE GEOCHEMICAL EXPLORATION}

In the HSSR program, reconnaissance geochemical exploration can be readily defined as any method which employs a systematic search for favorable uranium terranes by detecting one or more elements in sampling media. The analytical precision (reproducibility) required generally needs only to be quantitatively accurate enough to distinguish above and below background (Lovering et al, 1956). However, it is necessary to be able to analyze accurately concentrations of uranium as low as 0.01 parts per billion ( $p p b$ ) in water samples because uranium concentrations in many environments are extremely low.

All of the laboratories use delayed neutron counting to analyze at least part of their samples. This method has proved to be precise, as well as rapid and inexpensive, for very low levels of uranium. Other major methods of analyses include neutron activation analysis (LASL, ORGDP), plasma-source emission spectrography (LASL, ORGDP), fluorometry (LASL, ORGDP), x-ray fluorescence (LASL), atomic absorption spectrophotometry (ORGLP, SRL), and spectrophotometry (ORGDP).

The media most commonly used in geochemical exploration are listed in Table I. Unfortunately no single medium is a panacea for the geologist, and the one selected depends on several variables, including the type of material available to sample, the geology, the climate, the topography, and the geochemistry of the element(s) sought.

Geochemical sampling can identify the presence and areal extent of new uranium districts and can extend old uranium provinces, but it cannot supply the third dimension--the depth of the body (Brown, 1971). Reconnaissance geochemical exploration is only one means of localizing areas of interest; for maximum success it is imperative to integrate all available methods of exploration and to utilize all geological, geochemical, and geophysical information available. In the HSSR, areas identified as favorable in the reconnaissance phase can then be used to guide detailed follow-up surveys.

III. THE SEARCH FOR URANIUM

During the complex decay of uranium to its various daughter products, several radioactive elements are formed that can be detected easily by direct radiometric methods. However, simple, rapid methods using a gamma-radiation detector such as a Geiger-Muller or scintillation counter are ineffective where a relatively thin inactive overburden covers an ore body (Bowie et al, 1971). Because uranium is soluble and because of the recent use of highly sensitive analytical technology such as neutron activation analysis, which permits fast and relatively cheap automation-type programs, the use of geochemical methods for exploration has yielded favorable results.

Uranium in most rocks occurs as an oxide in the +4 valence. In weathering zones of surficial environments, uranium is oxidized to the + 6 valence, which is easily leached from surface rocks and carried as the uranyl ion into solution in most natural waters. Hexavalent uranium generally stays in solution until it is absorbed or encounters a reducing environment where it is precipitated as an oxide or hydroxide. Organic matter in streams and lakes provides favorable surfaces for the precipitation of uranium. However, uranium also will precipitate with ferric and manganic hydroxides, particularly where $\mathrm{pH}$ and carbonate ion concentrations are low (Dyck et al, 1971 ). 
TABLE I

TYPICAL SAMPLE MEDIA USED IN RECONNAISSANCE GEOCHEMICAL SAMPLING

Media
Rocks
Soils
Organic Matter

Gases

Ground Waters

Stream Waters

Stream Sediments
Use

Helps to determine potential host rocks; used nainly in detailed surveys.

Extremely useful in areas of low relief, thick overburden, and arid climate; used predominantly in detailed surveys.

Some biogeochemical processes concentrate certain elements in plant tissues; extremely useful in semi-desert areas and in detailed surveys.

Due to radioactive decay, some daughter products may be detected depending on atmosphere and soil conditions.

Extremely useful in arid areas and give information on subsurface environment; commonly used in reconnaissance.

Waters circulate over large areas and are extremely useful in searching for soluble elements; most used in reconnaissance.

Useful in areas of high relief and give rough index of geology of catchment basin; commonly sampled in reconnaissance programs.

Uranium is extremely well suited for hydrogeochemical surveys because of its high solubility compared to most other metals (Bowie et al, 1971). General reviews describing hydrogeochemical prospecting are found in Hawkes and Webb (1962), Bradshaw et al (1973), and Levinson (1974) among others. However, uranium mobility depends on several factors, inciuding the time of year, weathering and erosion, $\mathrm{pH}$, $\mathrm{Eh}$, absorption, the substrata permeability in contact with the uranium-bearing water, and the content of clay minerals in sediments. In the HSSR program, time and funding constraints require that any fielt measurements taken are a maximum aid in data evaluation, yet require minimun field time to conduct. The field measurements routinely taken by each laboratory are listed in Table II.

Sample Media Used in the HSSR Program

In the HSSR program, stream water, ground water, and stream sediments are the major media used. However, plant tissues were used by ORGDP and SRL in pilot studies, and helium samples are collected by SRL in pilot and reconnaissance studies and by ORGDP in detailed surveys. Because much of Alaska is extensively covered by lakes, LASL collects lake waters and lake sediments. The type of sample collected in any area depends on the results of extensive 
literature research of studies in similar terrane having comparable geology and geography (Table LI).

Stream waters may be most iseful in the broad-scale detection of anomalous areas in both reconnaissance and detailed exploration programs (Saukoff, 1956; Grimbert and Loriod, 1958; Boberg and Runnells, 1971). This aedium is an invaluable tool. in heavily forested and mountainous terrane. According to Fix (1956), uranium in most natural waters can be sonsidered to be a rough index of the uranium content of nearby geologic formations. However, natural waters must come into contact with mineral deposits and remain in rontact with them long enougil for some ore and/or indicat.re elements to dissolve and form dispersion patterns. A knowledge of how compler hydrologic sysiems work is essentia? in the detilized interpretation of geochemioal data.

Ground waters, because of their long residence time in hydrolosic systems and intimate contact with subsirface rocks, have the potential to contain more dissolved minerals than surface streams, thus providing invaluable subsurfice data. Samples of well water and spring water may be partioularly valuable for exploration in arid regions where zround waters may be the only agueous nedilim aviailable to sample (Boyle et $a l$, 1971). This medium is also useful in humid areas, where surface streams contain low urinium concentrations due to continual exposure of outcrops to rain and consequent. leaching and removal of soluble uranium, and dilution (Little and Durnam, 1971). For optimum use, sround water samples should be taken from aquifers at known depths (Denson et al, 1956).

Stream sediments (wet or dry) also are valuable indicators in outlining geochemical provinces. In the last 12 years, stream sediment surveys have been the chief metiod for geochemical reconnaissance exploration (Rose, 1977). Information from sediment samples can be related directly to the catchment basin of each siream. This medium is not affected direstly by climatic changes as readily as sirface waters are. Consequently, uranium valides in sediment samples are generally more consistent and jield more easily recognizable anomalies than do uranium values in surface waters. In areas of high relief or in desert areas, stream sediment samples may be the only availiale sample medium. In Sweden, stream sediments have been used extensively (Bruntin and Nairis, 1972) and as a geochemical prospecting medium they are considered more useful than water samples by some authors (Morse, 1971). Investigators differ as to which type of sediment sample to coliect; Morse (1971) favors samples composed of clastics, and Dyck et al (1971) favor organic-rich samples.

In some regions of Alaska, the terrain is extremely flat and large areas are underlain by permafrost. The low relief resilts in complex and disrupted drainage systems with poor circulation and sediments that are irregularly deposited; therefore, lake waters and lake sediments may give the best ipesults in these areas. Because water samples from Alaskan lakes generally jave very low uranium concentrations, precise measurements of uranium at the 0.5 parts per billion (ppb) level are needed. Dyck et al (1971) have shown that lake sampling in parts of the Canadian Shield is effective in delineating areas favorable for future exploration and is faster than stream sampling; however, they emphasized that lakes should be sampled near inlets or outlets to obtain best results. Other surveys utilizing lake samples include MacDonald (1969), Neyer (.369), Boyle et al (1971), and Dyck (1974).

Various combinations of media may provide the optimum exploration method. For example, in a rain-forest terrane, a stream water (and possibly stream sediment) sample coupled with a vegetation sample might be best. Each particular physiograpicic province should be studied separately, and all sampling 
TABLE II

FIELD MEASUREMENTS, NOMINAL SAMPLING DENSITIES, AND CHEMICAL ANALYSES FOR THE HSSR PROGRAM

\begin{tabular}{|c|c|}
\hline $\begin{array}{c}\text { Rocky } \\
\text { Mountains }\end{array}$ & Alaska \\
\hline
\end{tabular}

Field Measurements

$\begin{array}{llll}\mathrm{pH} & \mathrm{pH} & \mathrm{pH} & \mathrm{pH} \\ \text { temperature } & \text { temperature } & \text { temperature } & \text { temperature } \\ \text { conductivity } & \text { conductivity } & \text { conductivity } & \text { conductivity } \\ \text { ground radio- } & \text { ground radio- } & \text { ground radio- } & \text { ground radio- } \\ \text { activity } & \text { activity } & \text { activity } & \text { activity } \\ & \text { dissolved } & \text { total alkalinity total alkalinity } \\ \text { oxygen } & \text { (phenolphthalein, } \\ & & \text { mixed-indicator) } \\ & & \text { dissolved oxygen }\end{array}$

Media and Nominál

Sampling Densities

Stream waters
Stream sediments
Ground waters

Lake waters

Lake sediments

Organic matter

(plant tissue)

Helium

Chemical Analyses
$\mathrm{Ag}, \mathrm{Al}, \mathrm{Au}, \mathrm{Ba}, \mathrm{Be}, \mathrm{Ca}, \mathrm{Cd}$, $\mathrm{Ce}, \mathrm{Cl}, \mathrm{Co}, \mathrm{Cr}, \mathrm{Cs}, \mathrm{Cu}, \mathrm{Dy}$, $\mathrm{Eu}, \mathrm{Fe}, \mathrm{Hf}, \mathrm{K}, \mathrm{Li}, \mathrm{La}, \mathrm{Lu}$, $\mathrm{Mg}, \mathrm{Mn}, \mathrm{Na}, \mathrm{Ni}, \mathrm{Nb}, \mathrm{Pb}, \mathrm{Rb}$, $\mathrm{Sb}, \mathrm{Sc}, \mathrm{Sm}, \mathrm{Sn}, \mathrm{Sr}, \mathrm{Ta}, \mathrm{Tb}$, $\mathrm{Th}, \mathrm{Ti}, \mathrm{U}, \mathrm{V}, \mathrm{W}, \mathrm{Yb}, \mathrm{Zn}$

Water
$10 \mathrm{~km}^{2}$

$10 \mathrm{~km}^{2}$

$10 \mathrm{~km}^{2}$

(springs and

wells)

$\begin{array}{ll}-- & 23 \mathrm{~km}^{2} \\ -- & 23 \mathrm{~km}^{2} \\ -- & -- \\ -- & --\end{array}$

ORGDP

\section{SRL}

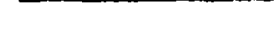


media should be thoroughly tested in the orientation studies (Bradshaw et al, 1973; Levinson, 1974), particularly if vegetal or biogeochemical type media are used. Biogeochemical studies have been used with some success especially in arid areas (Bowie et al, 1971). For example, in the Colorado Plateau, $a$ deep-rooted vetch, Astragalus pattersoni, requires considerable selenium to grow. Because selenium is associated with uranium deposits in this area, this species can be used as an ore guide (Massingill, 1979). However, biogeochemical studies involve complex interrelationships between geology, soil science, botany, and ecology and should be used with extreme caution (Levinson, 1974).

Ancillary Elements

In searching ror uranium deposits, the major element of interest is obviously uranium. But certain other elements may form a much wider dispersion halo resulting from their chemical behavior and weathering characteristics and may act as supplemental indicators of uranium. The indicators or pathfinder elements most commonly used in uranium exploration are molybdenum, sulphur, lead, arsenic, vanadium, zinc, copper, nickel, cobalt, and thorium (Hawkes and Webb, 1962). Other elements, sixch as gold, tin, and tungsten can be analyzed for their own worth. Fare-earth elements provide a basis for in-deptin geochemical studies, particularly with respect to uranium mobilization and ore genesis. In general, the more elements sought, the more potential value the analytical data have. The particular elements selected for analysis by tine respective laboratory depend on pilot surveys, analytical facilities, and funding constraints (Table II).

\section{SETTING UP AN HSSR PROGRAM}

From the principles first applied by Russian scientists in the early 1930s, geochemical exploration has evolved tremendously. Reviews of geochemical exploration for uranium have been compiled by Boyle et al (1971), Bowie et al (1971), Crimbert (1972), Dall'Aglio (1972), and Rose (1977), among others. In addition, large-scale geochemical surveys have been conducted in Canada, Finland, France, Norway, United Kingdom, and the USSR, as well as the NUnE in the US. Most procedures and ideas reviewed in this paper are a direct consequence of similar programs developed in other countries and standard geochemical sampling practices summarized by Hawkes and Webb (1962) and Levinson (1974).

In a program with the magnitude of the HSSR, certain problems are irherent. More than one million samples will be collected from more than 650000 locations. Sample analyses must be edited so that they are analytically correct and site locations are checked for accuracy before the data are reported to the public. Lastly, the samples need to be archived for future reference.

In the HSSR, the goal is to sample the conterminous US and Alaska so that areas favorable for uranium exploration are delineated on a regional scale. In all likelihood, data from the HSSR program will not identify ore bodies, but rather, they will help outline geochemical provinces and delineate areas favorable for detailed follow-up studies. To accomplish this, the five basic steps cited in Table III were followed. Because the different regions of responsibility contain extensive mountainous areas, basins, piedmonts, and desert terrane, each laboratory devel uped its own program.

Initially, a thorough literature research was conducted. The geochemistry of uranium as well as regional information on the type of geology, climate, 
TABLE III

STEPS IN SETTING UP AN HSSR PROGRAM

1. Goals Outlined.

2. Leadership and Experience.

Experienced management helps to minimize program costs.

3. Literature Research of Selected Area.

This research includes examination of all available information pertaining to the area of study. Topics should include physiography, geology, structure, hydroiogy, climate, known types of mineralization, geochemistry of element(s) sought, and case histories.

4. Pilot Studies.

All variables--how to collect the sample, which samples to collect, and how to treat the sample--should be fully examined. At the conclusion of the pilot study, a manual of systematic procedures is prepared and followed during later collection of samples from comparable terranes.

5. Logisties.

This includes studying the feasibility of subcontracting and methods of quality assurance for both field and analytical data. Report preparation, dissemination of data, and follow-up or detailed studies and how they are to be implemented are also consideren.

structure, known types of ore deposits in the area, proven methods of exploration, and various types of equipment available for field sampling and field measurements were all examined. Based on this research, an initial program was set up by each laboratory.

Because uranium deposits seldom accur under simple geochemical conditions, j.t is necessary to test all methodologies and sampling philosophies. Pilot and orientation studies provide the framework to understand the geometry, size, and type of dispersion jatterns that may exist and how they are influenced by geology, climate, and topography (Lovering et al, 1956). Pilot studies should be conducted in the vicinity of known uranium deposits where the extent of dispersion halos for anomalies related directly to ore bodies can be determined. Avoid areas contaminated by human activity so that natural geochemical patterns can be observed and compared to background levels in unmineralized terrane (Hawkes and Webb, 1962). This constraint may limit studies to small deposits. The combination of pilot projects undertaken should cover the f'ull range of environmental and climatic conditions typical of the reconnaissance region. It is also necessary to test, modify, and improve technical parameters and limits of the program until a methodology is developed that satisfies the goals of the overall program. Some considerations in designing and undertaking an HSSR program are listed in Table IV; the pilot study areas completed by the laboratories are shown in Fig. 1. 
TABLE IV

TECHNICAL PARAMETERS TO CONSIDER IN DESIGNING AND UNDERTAKING AN HSSR PROGRAM

A. Geology

a) lithologic regimes

b) structural controls

c) geomorphology

d) weathering profiles

e) ore ocourrences (mineralized areas)

f) uranium concentrations, background vs anomalous

g) uranium and indicator element geochemistry

h) dispersion patterns

i) area to which pilot applies

B. Hydrology
a) climatic regimes
b) seasonal variations
c) precipitation
d) surface waters (drainage area, flow rates)
e) ground waters (aquifers, recharge rates)

C. Sample Types
a) surface waters (streams, lakes)
b) ground waters (springs, wells)
c) sediment (wet--dry)
d) others (gases, plant tissue)
e) amount of sample to collect
f) relation among different media
g) influence of topography

D. Sample Spacing (Reconnaissance Scale)

a) minimum

b) maximum

c) optimum for each sample type

E. Sample Location

a) where to take samples

b) potential contaminants

F. Sample Preparation

a) water--no treatment, acidification, filtration, ionexchange concentrations

b) sediment--sieving, type of sieve material, drying considerations, crushing, icid leach

c) storage problems

d) adequacy of analytical facilities

G. Sample Containers
a) water--glass botties, poly- ethylene, teflon
b) sediment--polyethylene, paper, or cloth bags
c) storage problems

The individual laboratories have developed a field procedures manual explaining the purpose of the program for their area of responsiblity; the care, calibration, and use of field equipment; and general procedures to be followed for all aspects of the program. Because varying methods of sample collection and preparation affect the effectiveness of geochemical surveys, field procedures and equipment are continuously being updated, and pilot studies are conducted for each new region so that the manuals are revised as necessary.

The DOE laboratories subcontract the majority of their sample collection responsibilities. The samples are collected according to systematic and standardized sampling procedures that are outlined in sample collection manuals. All field equipment necessary to collect samples and to take and record the required measurements, including sample containers and data forms, are provided by the laboratories. At least two sets of maps which contain either a grid 
outlinge or preseleated sample locations are also provided. Field personnel are requi/sed to attend a short training course where the objectives of the program, samp/ing methodology, and care and calibration of field equipment are taught. Samrilers are required to be able to read a map and recognize geologic regimes. The DOE provides identification cards which are issued by laboratory personnel after a prospective sampler attends the training course. In addition, each laboratory provides a public relations brochure, written for the layman, explainj.ng the HSSR. Laboratory personnel are present in a supervisory capacity during all ispects of the sampling and provide help with equipment malfunctions and gaining access to properties, as wiell as with monitoring the program. In addition, IAASL, ORGDP, and SRL require field orews to keep a composite $1^{\circ} \times 2^{\circ}$ NTMS quadrangle map showing the progress of the contract.

Contract areas generally cover one or more NTMS quadrangles. Access is provided by the subcontractor and usually involves use of foun-wheel drive vehicles. However, sample collection in some mountainous terranes requires horses or backpacking. Most areas in Alaska are sampled by use of helicopters.

\section{FIELD MEASUREMENTS}

There are many chemical factors that control the solubility of uranium in water, several of wilich are listed in Table V. A review of the literature shows disagreement as to which measurements are most important; uranium itself is the best indicator of urarium deposits. of the measurements listed in Table $V$, the following are relabively easy to routinely measure in the field.

pH - In general, as $\mathrm{pH}$ decreases, uranium content increases. However, because uranium is soluble over such a wide range of pH (Grimbert and Loriod, 1968), $\mathrm{pH}$ is important to interpretation only when extreme values are encountered (Ostle and Ball, 1973).

conductivity - Uranium concentrations in waters from a given region generally correlate with concentrations of major components (approximated by conductivity), i.e., an increase in conductivity wijl usually correspond to an increase in uranium content in natural waters (MacDonald, 1969; Dall'Aglio, 1971; Dyck, 1975).

temperature - The temperature of water affects the rate of chemical and biological reactions which may influence the concentration of uranium (Fix, 1956; Ostle and BaIl, 1973).

TABLE V

SOME PARAMETERS TO BE CONSIDFPED IN FIELD MEASUREMENTS

$\mathrm{pH}$

conductivity

temperature

ground radioactivity

alkalinity dissolved oxygen

Eh

bicarbonate

chloride

sulfate 
equjvalent uranium - Scintillometer measurements of "shield in" and "shield out" readings allow an equivalent uranium value to be calculated, which then can be used as a ground truth tie for airborne radiometric data. A high equivalent value may be an indication of mineralization of uranium and thorium daughter products (Whitehead and Brooks, 1969).

In general, field measurements are taken by use of small, lightweight, battery-operated portable field instruments (Figs. $2 \mathrm{~A}$ and $2 \mathrm{~B}$ ). Typical $\mathrm{pH}$ meters weigh about $0.5 \mathrm{~kg}$, can be easily calibrated in the field, are temperature compensated, and have a $\pm 0.1 \mathrm{pH}$ precision. Spare probes can readily be exchanged. Conductivity meters, similar in size and weight to the $\mathrm{pH}$ meters, can measure up to $50000 \mu \mathrm{mho} / \mathrm{cm}( \pm 1 \%)$ and are easily calibrated by use of a standardized $\mathrm{KCl}$ solution.

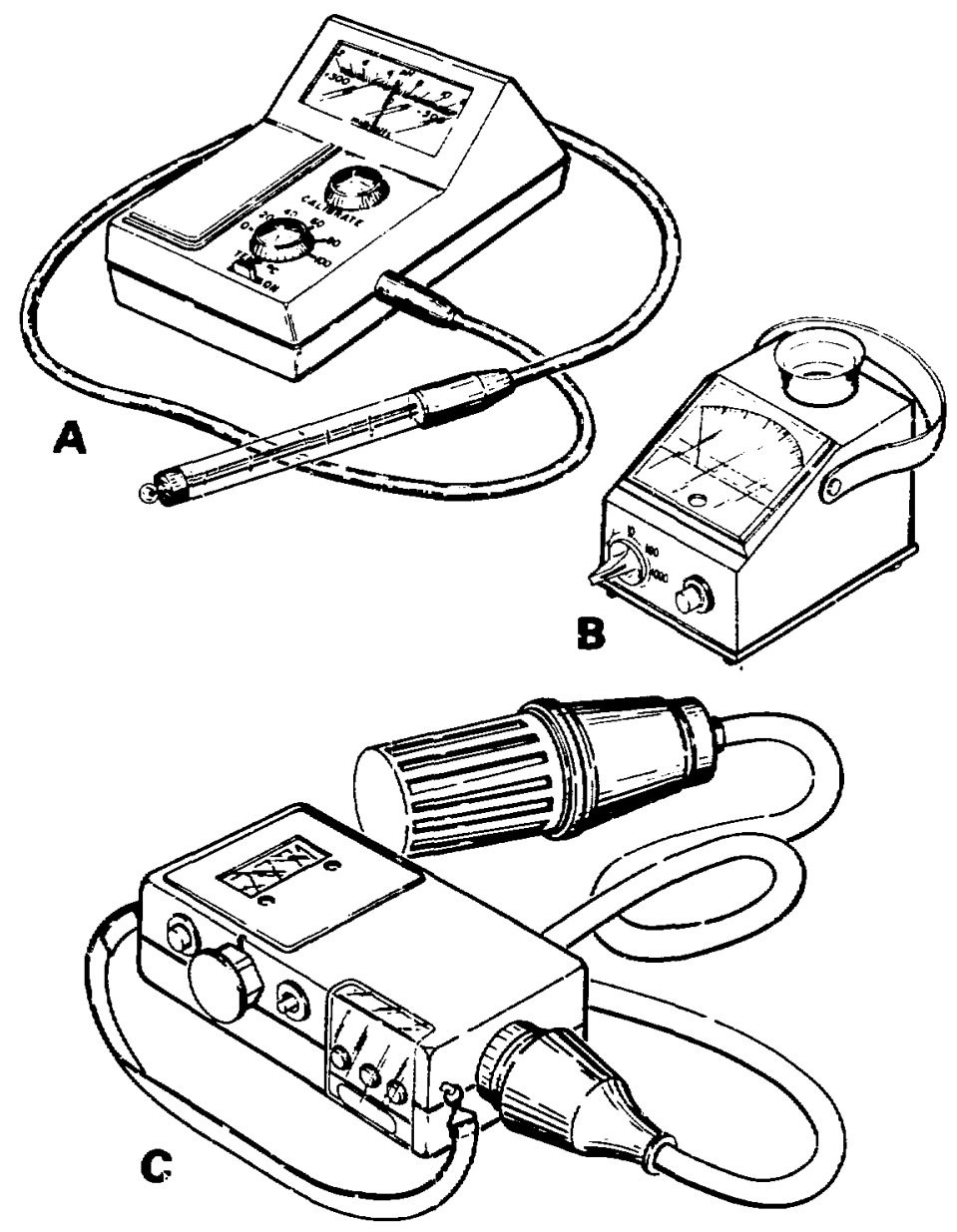

Fig. 2. Typical field instruments used in the HSSR program ( $A=p H$ meter, $\mathrm{B}=$ conductivity meter, $\mathrm{C}=$ water quality monitor). 
All teinperatures are measured with precalibrated thermometers. The air temperature in the shade is recorded to the nearest Celsius degree. The water temperature j.s usually recorded to the nearest $0.5^{\circ} \mathrm{C}$.

Several types of instruments that combine $\mathrm{pH}$, conductivity, temperature, and dic-olved oxygen measurements are also available. These water quality monitor sre generally lightweight instruments having the versatility of making severa tifferent measurements with only one piece of equipment (Fig. $2 C$ ). They art ideal for use in areas of difficult access. Temperature $\left(0\right.$ to $40^{\circ} \mathrm{C}$, $\left.\pm 0.5^{\circ} \mathrm{C}\right)$, conductivity $(0-2000 ; \mathrm{mho} / \mathrm{cm}, \pm 5 \mu \mathrm{mho} / \mathrm{cm}), \mathrm{pH}(0$ to $14, \pm 0.1 \mathrm{pH})$, and dissolved oxygen ( 0 to 20 parts per míllion $(\mathrm{ppm}), \pm 1.0 \mathrm{ppm}$ ) can usually be measured. Most types are battery operated and can be recharged. Alkalinity measurements are usually performed with field titration kits. Ground radioactivity is measured with portable scintillometers.

\section{SAMPLE COLLECTION}

In a program of this magnitude, thousands of sedinent samples are handled during peak periods. Because samples are analyzed for both uranium and a variety of other elements, any material that comes in contact with the sample could drastically affect the trace element data. Consequertly, a method to collect (usually some sort of plastic scoop) and transport the sample (either a plastic or paper bag) had to be determined. All laboratories analyze the fine-sized fraction that passes through a 100 mesh screen.

Some water samples contain abundant sispended material. This material may requj.re filtration because the suspended matter may contain additional uranium that is not in solution. All laboratories filter their water samples. Depending on the weight and size limitations of sample gear, several different filter models are used. One lightweight type used by LASL j.s shown in Fig. 3A. A slightly different and heavier model used by SRL utilizes a fluorocarbon gas canister that can apply pressure up to 40 psi (Fig. 3B).

$\underline{\text { LASL }}$

The LASL collection procedures are written for samples collected either in the Rocky Mountain states or in Alaska (Sharp and Aamodt, 1978).

Water samples. In the Rocky Mountain states, $50 \mathrm{ml}$ of water are collected in two $25-\mathrm{ml}$ vials that have been prewashed with dilute nitric acid. Ground-water samples from both wells and springs are collected as near the emergence source as possible. Holding tanks are not sampled. Stream waters are collected from the flowing current away from the bank. All waters are filtered through a $0.45-\mu$ membrane and acidified to $\mathrm{pH} \leq 1.0$ with $8 \mathrm{M}$ reagentgrade nitric acid. All water measurements are made with instruments previously discussed (Fig. 2).

In Alaska, $50 \mathrm{ml}$ of water are collected, but because of the water purity and due to the high costs per sample location, the time-consuming operation of filtration is omitted. Measurements are usually taken with a water quality monitor (Fig. 2C). In addition to standard field measurements (Table II), dissolved oxygen is determined for all Alaska water samples.

Sediment Samples. Up to $1 \mathrm{~kg}$ of sediment is collected from at least three adjacent spots at each location. The sample is usually collected with a polyethylene scoop. The sediment must be water transported and taken below the water level (if water is present) and must contain enough organic-rich, fine-grained particles to fill a 25-ml polyethylene vial. In lake areas in 

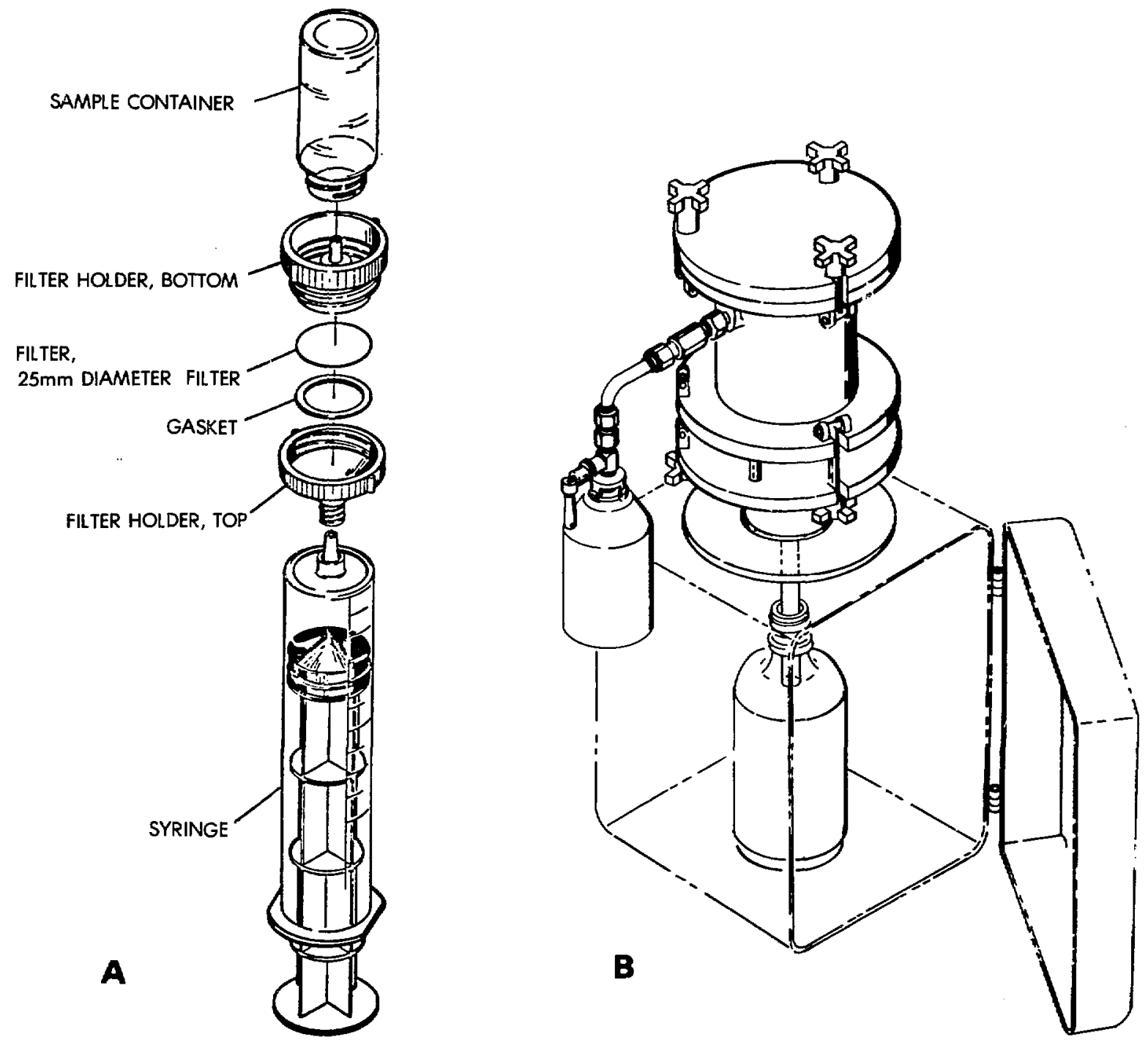

Fig. 3. Typical filter assemblies used in the HSSR program ( $A=$ LASL standard 50-ml syringe filter assembly, $B=S R L$ pressure filter assembly).

Alaska, the sediment is collected with a specially designed 11-kg, suctionoperated bottom sampler that can be dropped from the side of a helicopter (Fig. 4). After collection, sediments are put into a rip-top polyethylene bag and double labeled with the sample location number. The samples are dried at $\leq 100^{\circ} \mathrm{C}$ and sieved to -100 mesh by the subcontractor. Ground radioactivity measurements are taken at all sites.

ORGDP

The ORGDP collects either ground-water (Oak Ridge Gaseous Diffusion Plant, 1978a) or stream-water, stream-sedimeni samples (Oak Ridge Gaseous Diffusion Plant, 1978b). 


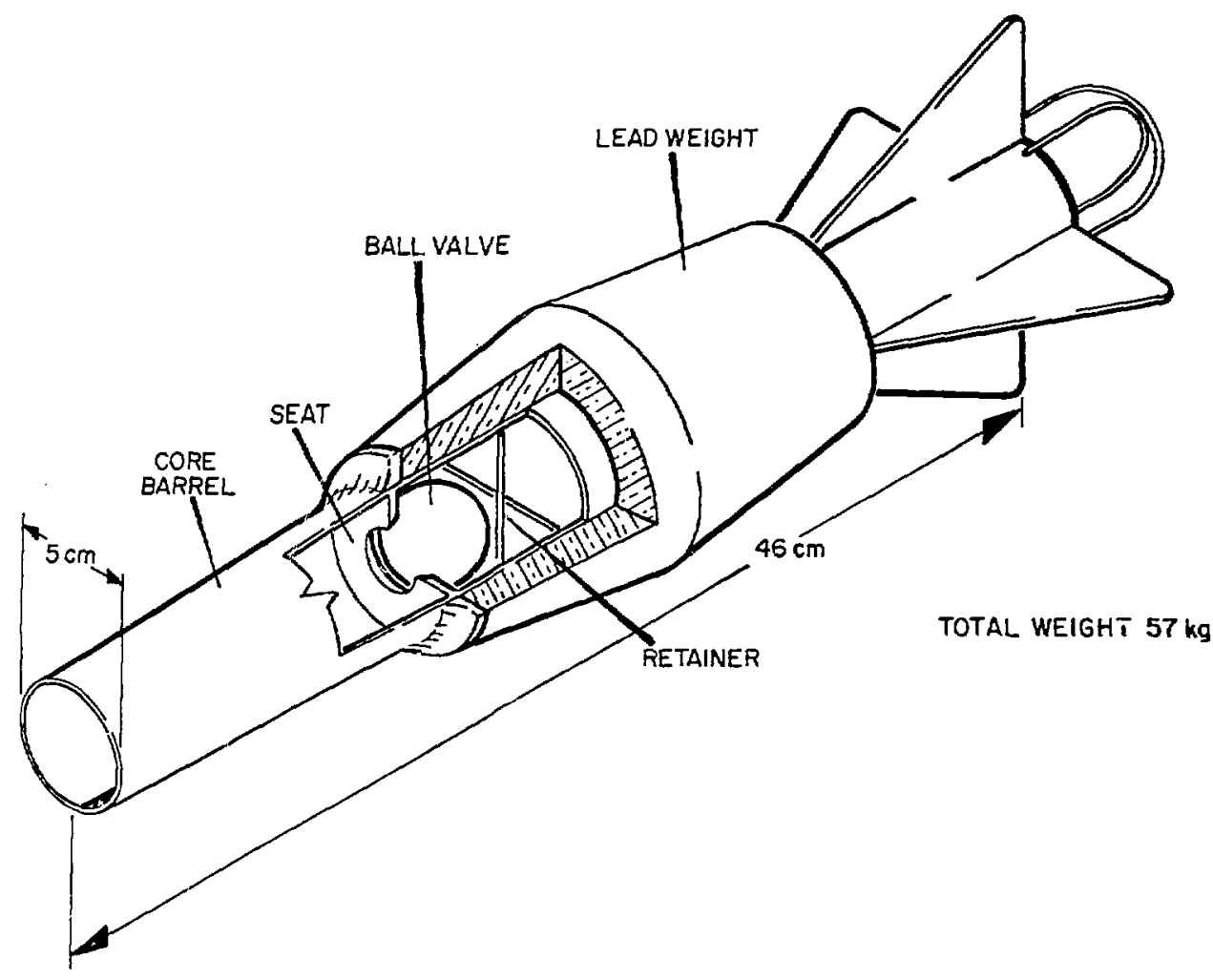

Fig. 4. Bottom sampler used to obtain lake sediments in Alaska.

Ground Water. Well or spring waters are collected. After flushing the system and rinsing the water containers, two 250-ml polyethylene bottles are filled. The samples are taken as close to the wellhead as possible, but all treated water and holding tanks are avoided. The samples are then sent to ORGDP for filtering through a $0.45-\mu \mathrm{m}$ cellulose acetate paper and analysis. All field measurements (Table II) are made with a water quality monitor (Fig. 2C) that has been in operation for at least two minutes. This instrument is calibrated daily. In addition, total alkalinity, phenolphthalein alkalinity, and mixed-indicator alkalinity are determined with an alkalinity test kit.

Stream Samples. Stream sediment or stream samples are collected from all basin locations. Stream waters are collected at the point of maximum flow. After a water sample is collected, the same field measurements are made as for a ground water sample. Sediment samples are gathered with a scoop and collected parallel to the longitudinal axis of the stream. The sample consists of a composite of several samples taken 2 to $3 \mathrm{~m}$ apart. The sediment is collected from the active portion of the stream and all organic, windblown, and floodplain materials are avoided. At least $25 \mathrm{~g}$ of the -100 mesh fraction are required. After collection, the sample is placed in a paper envelope, sealed with vinyl tape and sent to ORGDP. It is then dried at $85^{\circ} \mathrm{C}$ and sieved to -100 mesh. 
$\underline{\text { SRL }}$

The SRL samples are collected according to procedures outlined by Price and Jones (1979). Sample procedures vary according to sample type and climate and are grouped according to ground water, surface stream taken in humid areas, or surface stream taken in arid areas.

Ground Waters. Spring and well-water samples are collected as near the source as possible. Well systems are thoroughly flushed before sampling. All treated waters (e.g., chlorinated) and samples from holding tanks are avoided. After rinsing sample containers, about $2 l$ of water are collected. Samples are filtered through a 0.8- $\mu \mathrm{m}$ Nuclepore membrane in the field by use of a pressure filter apparatus (Fig. $3 \mathrm{~B}$ ). Temperature, $\mathrm{pH}$, and conductivity measurements are taken on the unfiltered water samples by instruments similar to those shown in Figs. 2A and 2B. About $50 \mathrm{ml}$ of filtered water are used for alkalinity measurements that are made with a field titration kit.

Because of both the low urarium concentrations in water samples in the eastern US and sample preservation problems, SRL developed a field ionexchange prosedure. About $1 \ell$ of water with a conductivity of $500 \mu \mathrm{mho} / \mathrm{cm}$ or less is mixed with $10 \mathrm{~g}$ ( $4 \mathrm{~g}$ dry weight) of 100 - to 200-mesh high purity cation-anion exchange resin. For samples exhibiting conductivity values greater than $500 \mu \mathrm{mho} / \mathrm{cm}$, a smaller volume of weter is used. The ion exchange resin is mixed for about 10 minutes using a battery-operated stirrer. The resin is then allowed to settle into the original 2-oz bottle, which is sent to SRL for analysis of its contents.

Dissolved helium is measured for all ground water samples. The collection technique, modified from Dyck et al (1976), uses a clean, 10-oz soft drink bottle. The filled bottle, less $2 \mathrm{ml}$ of water, is then capped, inverted, and then sent to SRL for analysis.

Surface Streams Taken in Humid Areas. Sample procedures and measurements for stream water samples are identical to those for ground water samples. In addition, $60 \mathrm{ml}$ of filtered water are collected in a 2-oz bottle containing $1 \mathrm{ml}$ of $8 \mathrm{~N}$ ultrapure nitric acid.

A sediment sample is collected either by use of a spring-loaded jaw scoop (for silty to rocky stream bottoms) or by a bag sampler consisting of a stainless steel tube with an attached bail and bag (less rocky bottoms). At least five sediment samples spaced along $30 \mathrm{~m}$ of the stream are composited. A stainless steel sieve is used to field screen the sediments and the -40 mesh fraction is retained. About $0.5 \mathrm{~kg}$ of the -40 mesh fraction is then placed into a Kraft paper bag and labeled. Samples are dried at 90 to $100^{\circ} \mathrm{C}$ before sending them to SRL.

Surface Streams in Arid Areas. Pilot surveys have determined that soil samples from arid areas generally are as effective as stream samples from arid areas, although dry wash areas are avoided when stream beds coexist in the same grid square. The sample procedure for dry sediments is the same as for wet sediments; however, the sample is usually collected with a shovel or trowel. If significant amounts of windblown sand are present, a composite of at least 15 separate areas is used. The sample is then sieved to a -18 to +40 and -40 mesh fractions. Both size fractions are then sent to SRL.

\section{FIELD OBSERVATIONS}

In a reconnaissance program, chances are high that any particular sample location will not be revisited. Therefore, it is essential to record all field 
measurements and observations at the site so that the information can later be user in data evaluation.

To do this, ezch laboratory has developed data forms on which the sampler can record the sample type, location, weather, possible contaminants, field measurements, and geologic observations. Field observations are number coded and can be recorded in minimal time. Each form has additional space for comments or clarification of information. Figure 5 is an example of the form used by LASL; it can be adapted for any type of sample normally collected. The SRL user separate data forms for ground water samples and surface samples in the eastern US prior to October 1978 but his adopted a standardized form for all sites in more recent sampling. The ORGDP uses the same data form for ground water, stream water, or sediment samples. The content of all data forms for all laboratories is similar.

In addition, each laboratory has systematic coded nlimbering systems. The LASL and ORGDP use prenumbered adhesive stickers whereas the SRL employs a system that requires writing the sample number on the sample containers. Each sample is coded so that the state and quadrangle from which is collected can be identified easily.

The following observations are generally recorded at each sample locainon.

location - All laboratories supply subcontractors with at least two copies of field maps. These maps are generally 7.5 minute $(1: 24000), 15$ minute

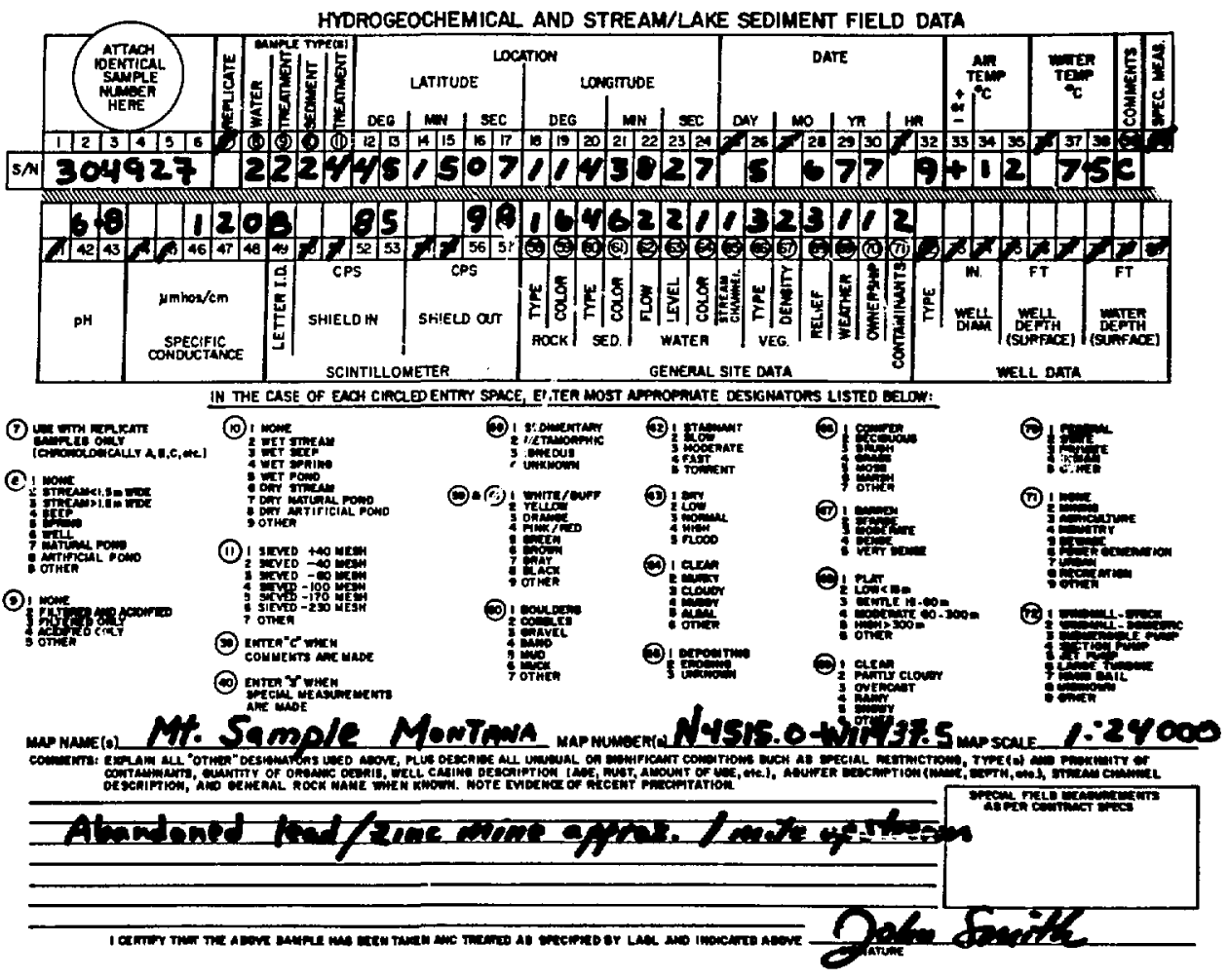

Fig. 5. Representative data form used in the HSSR program. 
(1:62 500), or county road maps. Each map contains a sample grid and/or premarked sample location. After sample collection, locations are transferred from the field map to an unrolled copy that can then be digitized at the respective laboratory for the latitudes and longitudes of the sample location. The SRL also requires a photograph of the site and directions for reaching the site.

weather - Seasonal climatic conditions may drastically affect uranium concentrations in surface waters and, to a much lesser extent, in sediments (Fix, 1956; Germanov et al, 1958; Doi et al, 1975; Rose et al, 1976). Consequently, hydrogeochemical surveys should be completed as rapidly as possible. During periods of high runoff, normal uranium concentrations may be diluted whereas after a prolonged drought, uranium concentrations in runoff may be increased for a short period (Peacock, 1961; Lopatkina, $1964)$.

relief - Several elements, including uranium, in both surface waters and sediments tend to have relatively short dispersion patterns in areas of high relief (Chamberlain, 1964). Furthermore, access to water may be difficult and sediment may be absent locally. Therefore, sample densities may have to be increased so that adequate coverage can be obtained. geology - Uranium content in both water and sediment generally reflects the local geology. For example, a stream flowing over carbonate terrane would be expected to have higher uranium content than a similar stream flowing across siliceous terrane because of complexing of uranium with carbonate ions (Levinson, 1974). Sediments from acidic igneous rocks generally have greater uranium concentration than sediments from other rock types (Rogers and Adams, 1970). Also, ground waters that circulate along fractures and faults may contribute significant amounts of uranium as well as other trace metals (Doi et al, 1975; Dyck, 1975). Consequently, the local geology may be the most help in the interpretation of the data.

contamination - All sources of contamination, such as mine waters, tailings, trash, and man-made structures (bridges, culverts, and well casings) are avoided where possible. However, any potential contaminant, such as uranium-rich phosphate fertilizers (Boiverg and Runnells, 1971), is noted on the data form.

vegetation - In terrane containing abundant vegetation, relatively short dispersion trains in surface water can exist. This generally results from organic matter absorbing uranium from the water and, consequently, increasing the uranium concentration in sediment (Dall'Aglio, 1971; Dyck et al: 1971).

\section{SAMPLING DENSITIES}

In reconnaissance exploration sampling, densities may range from one sample per $1.6 \mathrm{~km}^{2}$ to one sample per $160 \mathrm{~km}^{2}$ or even greater (Levinson, 1974). Dispersion haloes even for small deposits can ordinarily be detected as far a:s several hundred meters in ground water and up to several $\mathrm{km}$ in some streams. Large deposits in the western US can be detected many kilometers downstream (Fix, 1956). For a catchment area of 8 to $32 \mathrm{~km}^{2}$, the surface drainage and/or sediment dispersion pattern for a significant ore body may vary from 300 to $3200 \mathrm{~m}$ (Hawkes and Webb, 1962). Ostle (1954) was able to detect anomalies in surface waters over $10 \mathrm{~km}$ downstream from waste dumps. 
Canadian sunveys show that for areas extensively covered by lakes, similar information can be obtained on a grid of one sample location per $8 \mathrm{~km}^{2}$ compared to one sample location per $16 \mathrm{~km}^{2}$ (except for areas where deposits are very localized, Garrett, 1977). Clearly, the selected density depends on geology, hydrology, and climate. Complete coverage is not always possible for regions having poor access. One should choose a spacing so that at least two or more samples fall within the anticipated zone of an anomaly (Lovering et al, 1956). Based on an extensive research of similar studies in similar terranes, the laboratories have selected the nominal sample densities shown in Table II,

The following sections briefly describe the type of media sampled by each laboratory for its physiographic province. An extensive review of the geology and known and potential uranium hosts can be found in US Department of Energy Interim Report (1979).

LASL

Some 250000 sample locations will be taken from 2.7 million $\mathrm{km}^{2}$ of land in LASL's area of responsibility. The area includes most of the Rocky Mountain states and all $0 i^{\prime}$ Alaska (Figs. 1 and 6). Much of the Rocky Mountain region consists of rugged mountain ranges separated by intermontane basins. In these mountains and on their flanks, fast-flowing stream waters and their sediments are the major sample media. Well-water samples are the major sample media in the intermontane basins.

Part of the Colorado Plateau is also in the LASL region, and this area contains several uranium districts, including the Grants mineral belt in New Mexico, which is the largest uranium-producing area in the US. The climate in the Plateau region and in the southern part of the LASL area of responsibility is semi-arid. In these areas, well water samples are collected when possible, although in sparsely populated areas, dry stream beds may be the only available sampling media.

Alaska contains a diversity of physiographic provinces (Fig. 6). The northern and much of the interior of the state is underlain by regions of permafrost. These areas are extensively covered by lakes and, consequently, primarily lake water and sediments are sampled. Two mountain ranges cross the state, the Brooks Range in the north and the Alaska Range in the south. In these areas of fast-flowing streams, water and sediment samples are collected. The southeastern part of the state is not only rugged but also heavily vegetated. Therefore, primarily stream waters and stream sediments are collected here.

Based on several pilot studies, LASL selected a sample density of one location per $10 \mathrm{~km}^{2}$ for the Rocky Mountain states. All sample locations are preselected by LASL personnel. Surface streams are chosen to represent drainage areas of about $10 \mathrm{~km}^{2}$. Sites wich cannot be reached in the field are reselected to approximate the original drainage area as closely as possible. For sampling lakes in Alaska, a 23- $\mathrm{km}^{2}$ grid pattern is transferred onto field maps, and helicopter pilots then select locations near the center of each grid square. Streams are sanpled at twice this density.

ORGDP

The total area of responsibility for ORGDP is about 2.6 million $\mathrm{km}^{2}$ (Figs. 1 and 6). Samples in the northern regions are collected mostly from streams in marshlands. Much of the ORGDP area is within the Great Plains and Central Lowlands, which is comprised of generaliy low-lying topography. This 


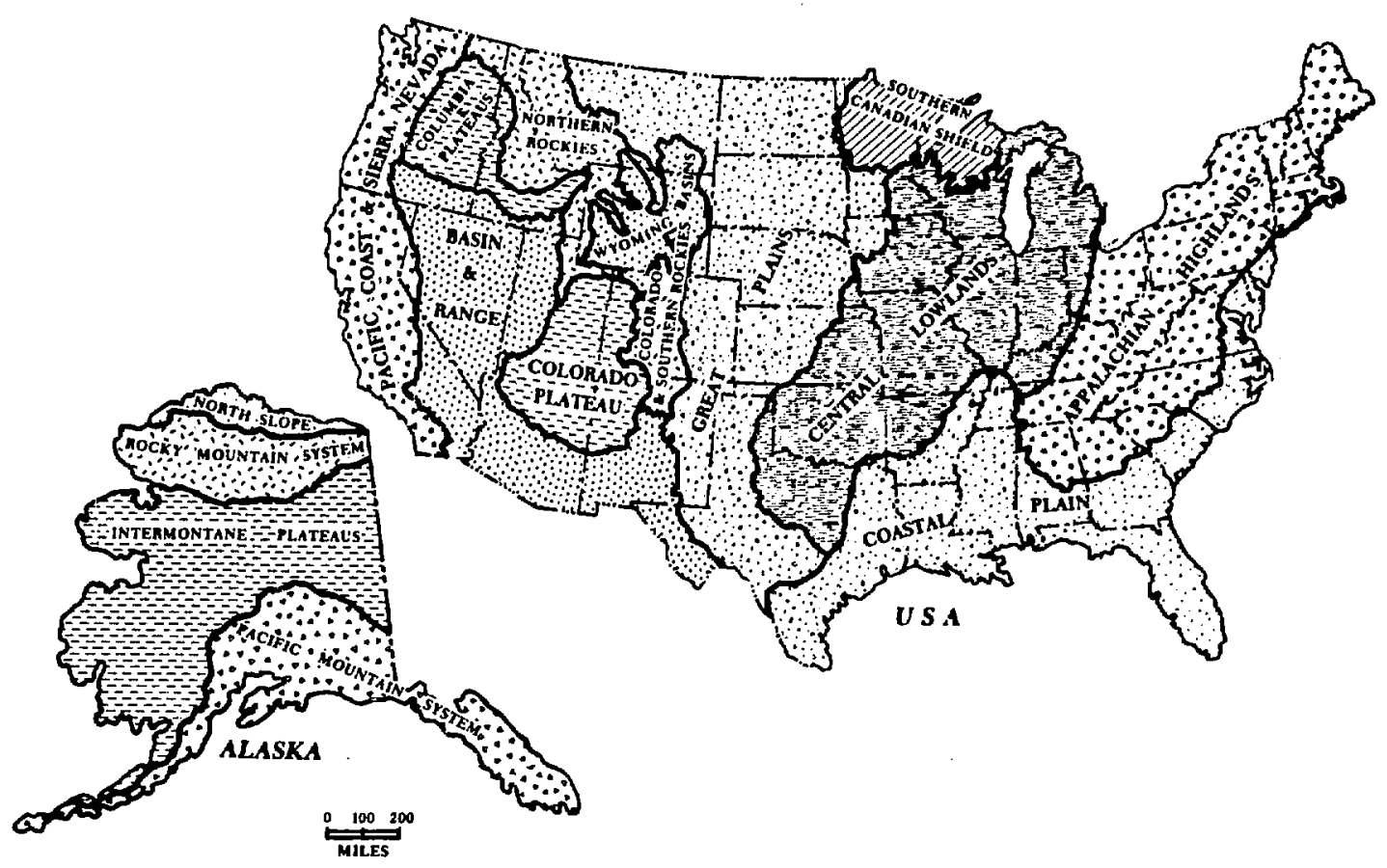

Fig. 6. Major physiographic provinces for the HSSR.

area is extensively farmed and, although aburdant, surface streams do not offer optimum samples. However, these lohilands are underlain by large ground-water aquifers and, consequently, ground-water samples predominate.

The southern area with its semi-arid climate contrasts sharply to the mid-continental US. There are also some known sandstone-type deposits in the Coastal Plain of Texas. Ground water provides the best sample media here because streams generally are dry and may contain windblown material.

The sample density of one location per $26 \mathrm{~km}^{2}$ predominantly reflects collection of ground water. All ground-water locations are chosen according to a grid system. A vell location is selected in a grid for which well log information exists. If a site cannot be reached, an alternate is picked by the sampler, but it is the sampler's responsibility io select a site near to and representative of ihe original and to collect the necessary well $l o g$ information (e.g., producing horizons, depth, and pump type).

Stream sample sites are selected according to considerations of drainage basins and drainage patterns. Sites are chosen by ORGDP personnel for basins that drain from 3 to $30-\mathrm{km}^{2}$ areas and average about $26 \mathrm{~km}^{2}$. Any site 10cations that samplers are unable to reach are reselected to simulate the original site as nearly as possible.

SRL

The SRL area of responsibility includes all or parts of 37 states in the eastern US and western US. The procedures described in this report gerierally refer to SRL's operation in the eastern US because they have only recently 
begun sampling in the westemn US (Figs. 1 and 6). Regions in the eastern JS consist predominaritly of roli.jng hills and piedmont-type topography. The climate in these areas is generally humid with significant rainfall and abundant vegetation. Both streams and ground-water sample media are available, bu: access onto private propericy may be jocally difficult.

The SRL region of responsinility in the western US inoludes part of the Basin and Range physingraphic province. Much of this area is semi-arid and sparsely populated. Consequently, availability of the ground-water medium may be at a minimum and stream beds may be dry and filled with windblown debris. In addition, much of the area has interior drainage, and evaporites and playas are common.

The Pacific Coast and Sierra Nevada consist predominantly of northtrending mountain ranges separated by valley systems. Fast-flowing streams are abundant, but access is a major problem.

The SRL locations are selected based on a random srid. A sample location, regardless of the sample type, is selected by the subcontractor for 10 to $30-\mathrm{km}^{2}$ areas; the average spacing is one site for every $13 \mathrm{~km}^{2}$. Rules of thumb are that no two adjacent grid squares can be left vacant, no two semple points can be closer tinan $1.5 \mathrm{~km}$, streams can drain no more than three times the area of the grid, and the largest stream which heads in a grid is usually sampled.

\title{
IX. DATA AVAILABILITY
}

The NURE HSSR program is one of the lapgest reconnaissance geochemical exploration programs at.tempted. By the completion of the program, mure than one million samples will be collioted from more than 650000 locations. All data are reported by $1^{\circ} \times 2^{\circ}$ National Topographic Map Series quadrangle boundaries (Fig. 1). Each quadrangle contains from 1000 and 3000 (normally 1500) sample locations; each sample location consists of one water and/or one sediment sample. Uranium and as many as 43 additional elements are reported ior each location, depending on sample type (Table II). All information is consjdered confidential. and not $r(u)$ private use until it is open filed. These data are then made available to the public. The magnetic tapes can be obtained from:

\author{
GJOIS Project \\ UCC-ND Computer Appiications Dept. \\ 4500 North Building \\ Oak Ridge National Laboratory \\ P. 0. Box X \\ Oak Ridge, Tennessee 37830 \\ Phone: (515) 574-5463
}

The reports are available from:

\author{
Bendix Field Engineering Corporation \\ Technical Library \\ Grand Junction Office \\ P. O. Box 1569 \\ Grand Junction, Colorado 81501 \\ Phone (303) 242-8621, Ext. 278
}




\section{ACKNOWLEDGMENTS}

The author wishes to thank David E. Broxton, Spencer S. Shannon, Jr., and Harry N. Planner who reviewed early drafts of this manusisut and made many helpful contributions. Nancy J. Eckhoff typed the nanuscript and $C$. A. Anderson drafted the figures. In addition, special thanks are die Van Price of the Savannah River Laboratory, Todd Butz of the Dak Ridge Gaseous Diffusion Plant, and N. King Stzinlein of Bendix Field Engineering Corporztion, Grand Junction Office, for their helpful suggestions. 
REFERENCES CITED

Boberg, W.W. and Runnells, D. D., 1971. Reconnaissance study of uranium in tile South Pla'te River, Colorado. Econ. Geol., 66: $435-450$.

Bowie, S.H.U., Ball, T.K. and Ostle, D., 1971. Geochemical methods in the detection of hidden uranium deposits, Can. Inst. Min. Metall., Spec. vol., $11: 103-111$.

Boyle, R.W., Hornibrook, E.H.W., Allen, R. J., Dyck, W. and Smith, A. Y., 1971. Hydrogeochemical methods-application in the Canadian Shield. Can. Min. Meta 11. Bull., 64: 50-71.

Bradshaw, P.M.D., Clews, D.R. and Walker, J.L., 1973. Exploration Geochemistry. Barringer Research Ltd. , Rexdale, Ont., 49 pp.

Brown, B.W., 1971. Geochemistry and ore exploration. Can. Inst. Min. Metall., Sper. vol., 11: 113-115.

Brundis, N.H. and Nairis, B., 1972. Alternative sample tjpes in regional geochemical prospecting. J.Geochem. Expl., 1: 7-46.

Chamberlain, J.A.: 1964. Hydrogeochemistry of uranium in the BancroftHa liburton Region, Ontario. Geol. Surv. Canada Bi1i., 18: $19 \mathrm{p}$.

Dall'Aglio, M., 1971. A study of the circulation of uranium in the supergene environment in the Italian Alpine Range. Geoch. Cosmochim. Acta, 35: 47-60.

Dall'Aglio, M., 1972. Planning and interpretation criteria in hydrogeochemical prospecting for uranium (with discussion). In: S.H.U. Bowie, M. Davis and D. Ostle (Editors), Uranium Prospecting Handbook, Institution of Mining and Metaj.Lurgy, London, pp. 121-134.

Denson, N.M., Zeller, H.D. and Stephens, J.D., 1956. Water sampling as a guide in the search for uranium deposits and its use in evaluating widespread volcanic units or potential source beds for uranium. US Geol. Survey Prof. Paper, 300: 573-680.

Doi, K., Hirono, S. and Sakamaki, Y., 1975. Uranium mineralig.ztion by ground wat,ar in sedimentary rocks, Japan, Econ. Geol.; 70: 628-646.

Dyck, W., 1974. Geochemical studies in the surficial environment of the Beaverlodge area, Saskatchewan. Geo.. Surv, Canada Paper, 74-32, 30 p.

Dyck, W., 1975. Geochemistry applied to uranium exploration. Geol. Surv. Canada Paper, 75-26: 32-47.

Dyck, W., Dass, A.S., Durham, C. C. , Hobbs, J. D., Pelchat, J. C. and Galbraitia, J.H., 1971. Comparison of regional geschemical uranium exploration methors in the Beaverlodge area, Saskatchewan. Can. Inst. Min. Metall., Spec. vol., 11: $132-150$. 
Dyck, H., Pelchat, J.C. and Meilleur, G.A., 1976. Equipment and procedures for the collection and determination of dissolved gases in natural waters. Geol. Surv. Canada Paper, 75-34: $10 \mathrm{p}$.

Fix, P.F., 1956. Hydrogeochemical exploration for uranium. US Geol. Surv. Prof. Paper, 300: 667-671.

Garrett, R.G., 1977. Sample density investigations in lake sediment geochemical surveys of Canada's uranium reconnaissance program. US DOE, Open file Rept., GJBX-77(77), pp. 173-185.

Germanov, A.E., Batulink, S.G., Volkov, G.A., Lisitin, A.K. and Serebrennikov, V.S., 1958. Some regularities of uranium distribution in underground waters. Proceedings 2nd UN InternationaI Conference on Peaceful Uses of Atomic Energy, Geneva, 2: 126-130.

Grimbert, A., 1972. Use of geochemical techniques in uranium prospecting (with discussion). In: S.H.U. Bowie, M. Davis and D. Ostle (Editors), Uranium Prospecting Handbook, Institution of Mining and Metallurgy, London pp. 110-120.

Grimbert, A. and Loriod, R., 1968. Geochemical prospecting for uranium (trans. from French). US AEC Off. of Info. Services, Springfield, VA, AEC-tr-7579, $38 \mathrm{pp}$.

Hawkes, H.E. and Webb, J.S., 1962. Geochemistry in Mineral Exploration. Harper and Row, New York, NY, 415 pp.

Levinson, A.A., 1974. Introduction to Exploration Geochemistry, Applied Publishing Ltd., Calgary, Alta., 612 pp.

Little, H.W. and Durham, C.C., 1971. Uranium in stream sediments in carboniferous rocks of Nova Scotia. Geol. Surv. Canada Paper, 70-54: 17 pp.

Lopatkina, A.P., 1964. Characteristics of migration of uranium in the natural waters of humid regions and their use in the determination of the geochemical background for uranium. Geochem. Int., 4: 788-795.

Lovering, T.S., Lakin, H.W., Ward, F.M. and Canney, F.C., 1956. The use of geochemical techniques and methods in prospecting for uranium. US Geol. Surv. Prof. Paper, 300: 659-665.

MacDonald, J.A., 1969. An orientation study of the uranium distribution in lake waters, Beaverlodge District, Saskatchewan. Colorado School of Mines Quarterly, 64: 357-376.

Massingill, G.L., 1979. Uranium indicator plants of the Colorado Plateau. New Mexico Geology, 1:49-52.

Meyer, W.T., 1969. Uranium in lake water from the Kaipokok Region, Labrador. Colorado School of Mines Quarterly, 64: 337-394. 
Morse, R.H., 1971. Comparison of geochemical prospecting methods using radium with those using radon and uranium. Can. Inst. Min. Meta11., Spec. vol., 11: $215-230$.

Oak Ridge Gaseous Diffusion Plant, 1978a. Procedures manual for groundwater reconnaissance sampling. US DOE, Open file Rept., GJBX-62(78), 19 pp. plus 5 appendixes.

Oak Ridge Gaseous Diffusion Plant, 1978b. Procedures manual for stream sediment reconnaissance sampling. US DOE, Open file Rept., GJBX-84(78), 19 pp. plus 5 appendixes.

Ostle, D., 1954. Geochemical prospecting for uranium. Mining Magazine, 91: 201-208.

Ostle, D. and Ball, T.K., 1973. Some aspects of geochemical surveys for uranium (with discussion). : In: Uranium Exploration Methods, International Atomic Energy Agency, Vienna, pp. 171-187.

Peacock, J.D., 1961. Uranium in British surface and underground waters. Nature, 191: 1189-1190.

Price, V. and Jones, P.L., 1979. Training manual for water and sediment geochemical reconnaissance. Savannah River Laboratory, Open file Rept., DPST-79-219, $104 \mathrm{pp}$.

Rogers, J.J.W., and Adams, J.A.S., 1970. Uranium. In: K.H. Wedepohl (Editor), Handbook of Geochemistry, v. II-2, chapter 92, Berlin, Springer Verlag.

Rose, A.W., Keith, M. and Suhr, N.H., 1976. Geochemical drainage surveys for uranium: sampling and analytical methods based on trial surveys in Pennsylvania. US ERDA, Open file Rept., GJBX-28(76), 34 pp.

Rose, A.W., Jr., 1977. Geochemical exploration for uranium. In: Sympasium on hydrogeochemical and stream sediment reconnaissance for uranium in the United States. US DOE, Open file Rept., GJBX-77(77), pp. 303-352.

Saukoff, A.A., 1956. Radiohydrogeological method in prospecting for uranium deposits. Proceedings UN International Conference on Peaceful Uses of Atomic Energy, Geneva, 6: 756-759.

Sharp, R.R., Jr. and Aamodt, P.L., 1978. Field procedures for the uranium hydrogeochemical and stream sediment reconnaissance as used by the Los Alamos Scientific Laboratory. US DOE, Open file Rept., GJBX-68(78), 64 pp.

US Department of Energy, 1979. National Uranium Resource Evaluation, Interim Report, June 1979. US DOE, Open file Rept., GJO-111(79), 131 pp.

Whitehead, N.E. and Brooks, R.R., 1969. A comparative evaluation of scintillometric, geochemical, and biochemical methods of prospecting for uranium. Econ. Geol., 64: 50-56. 